\title{
INHIBITORY ALPHA-ADRENERGIC ACTION OF PHENYLEPHRINE IN GUINEA PIG TAENIA CAECUM
}

\author{
Yumiko IWAYAMA, Issei TAKAYANAGI* and Yutaka KASUYA \\ Department of Chemical Pharmacology, Faculty of Pharmaceutical Sciences, \\ University of Tokyo, Bunkyo-ku, Tokyo 113, Japan
}

Accepted November 22, 1978

\begin{abstract}
Phenylephrine, a selective $\alpha$-adrenergic stimulant, caused a maximal relaxation of the taenia from guinea pig caecum in the concentration of $10^{-6} \mathrm{~g} / \mathrm{ml}$. Phenylephrine in this concentration did not influence intracellular cyclic AMP and cyclic GMP levels. Although phenylephrine abolished the spontaneous spike discharge, no change was detected in ${ }^{45} \mathrm{Ca}$-uptake and ${ }^{45} \mathrm{Ca}$-efflux on the tissue level after phenylephrine. Ca-uptake and Ca-release on the subcellular level were also not influenced by phenylephrine. In $\mathrm{Ca}$ free-solution phenylephrine inhibited the response to $\mathrm{CaCl}_{2}$. Phenylephrine increased ${ }^{42} \mathrm{~K}$-efflux in the normally polarized taenia and also in the K-depolarized taenia.
\end{abstract}

Adrenoceptors were classified as $\alpha$ - and $\beta$-receptors by Ahlquist (1). As a rule, $\alpha$ receptor is associated with the excitatory functions and $\beta$-receptor with the inhibitory functions. Exceptionally, stimulation of $\alpha$ - and $\beta$-receptors in an intestinal smooth muscle causes a relaxation (2). But the inhibitory responses mediated through $\alpha$ - and $\beta$-receptors are independent as to mechanical effects and metabolic effects (3).

It was reported that stimulation of $\beta$-adrenoceptors elevates the intracellular levels of cyclic AMP and facilitates Ca-accumulation (4). However, little is known of the mechanisms involved in the responses mediated through $\alpha$-adrenoceptors, except that an $\alpha$-adrenoceptor stimulant increases K-permeability (5-7). We carried out studies on the effects of an $\alpha$ adrenoceptor stimulant on tissue levels of cyclic nucleotides, Ca-movement and $\mathrm{K}$ permeability.

\section{MATERIALS AND METHODS}

Phenylephrine was used as the $\alpha$-adrenergic stimulant. Male guinea pigs (300-400 g) were sacrificed by a blow on the neck and two pieces of taenia were removed from one caecum and suspended in two $30 \mathrm{ml}$ organ baths filled with physiological solution kept at $32^{\circ} \mathrm{C}$ and bubbled with air. One was used for measuring the control levels of cyclic nucleotides and the other for estimating the change in levels of cyclic nucleotides after one min treatment with phenylephrine in the presense of propranolol. They were frozen in liquid nitrogen. Cyclic AMP was assayed with the method of Gilman (8) and cyclic GMP by the radioimmunoassay method of Steiner et al. (9) modified by Yasuda et al. (10). Protein content was determined by the method of Lowry et al. (11), using bovine serum albumin as a standard.

* Correspondence and Present Address: Department of Chemical Pharmacology, Toho University, School of Pharmaceutical Sciences, Miyama, Funabashi, Chiba 274, Japan 
Physiological solution used had the following composition (mM); $\mathrm{NaCl} 154, \mathrm{KCl} 5.6, \mathrm{CaCl}_{2}$ 2.2, $\mathrm{MgCl}_{2} 2.1, \mathrm{NaHCO}_{3} 5.9$ and glucose 2.8.

Experiments to test the effect of phenylephrine on membrane activity were done on strips of the taenia. Isolated taenia was mounted in the sucrose gap apparatus according to the method of Bülbring and Burnstock (12). In this apparatus, an arrangement was made to record isometric contractions of smooth muscle with electrical changes.

To examine ${ }^{45} \mathrm{Ca}$-uptake by the muscle, the isolated taenia was attached to a stainless holder and equilibrated for $1 \mathrm{hr}$ in physiological solution bubbled with air at $32^{\circ} \mathrm{C}$. At 2 , 5 and $8 \mathrm{~min}$ after incubating the taenia in physiological solution containing ${ }^{45} \mathrm{Ca}(3 \mu \mathrm{Ci} / \mathrm{ml})$ and phenylephrine, the tissue was removed from the solution, blotted with filter paper and quickly weighed. To determine ${ }^{45} \mathrm{Ca}$-radioactivity, the tissues were dissolved with Soluene 350 (Packard) and counted in a liquid scintillation counter.

To measure alterations of ${ }^{45} \mathrm{Ca}$-efflux, the tissues were also attached to a stainless holder and were equilibrated for $1 \mathrm{hr}$ in ${ }^{45} \mathrm{Ca}$-physiological solution $\left({ }^{45} \mathrm{Ca}, 30 \mu \mathrm{Ci} / \mathrm{ml}\right)$ and then at intervals of $10 \mathrm{~min}$ quickly transferred to a series of test tubes containing $3 \mathrm{ml}$ of inactive physiological solution at $32^{\circ} \mathrm{C}$ bubbled with air. One $\mathrm{ml}$ of solution from each tube was counted in a liquid scintillation counter. To detect any change in extracellular space of the taenia induced by the drug, ${ }^{14} \mathrm{C}$-sorbitol was used. After $10 \mathrm{~min}$ incubation with ${ }^{14} \mathrm{C}$ sorbitol and the drug, the radioactivity in muscles was measured.

To examine $\mathrm{Ca}^{2+}$-movements on the subcellular level, about 15 guinea pigs were sacrificed at one time and the taenia was immediately removed and washed with ice-cold $0.25 \mathrm{M}$ sucrose solution. The isolated taeniae were then cut into small pieces and homogenized in 10 volumes of $0.25 \mathrm{M}$ sucrose containing $10 \mathrm{mM}$ tris- $\mathrm{HCl}$ buffer (pH 7.4) by means of Polytron (PT-10, Brinkman Instruments) with a rheostat setting 6.5 for $5 \mathrm{~s} \times 3$. The homogenate was centrifuged for $15 \mathrm{~min}$ at $2,500 \times \mathrm{g}$ and the supernatant was again centrifuged for $20 \mathrm{~min}$ at $15,000 \times \mathrm{g}$. Centrifugation of the supernatant at $40,000 \times \mathrm{g}$ for $90 \mathrm{~min}$ resulted in a pellet which was used as the microsomal fraction. Ca-uptake was studied at $32^{\circ} \mathrm{C}$ in the incubation mixture which contained $(\mathrm{mM}) \mathrm{KCl} 100, \mathrm{MgCl}_{2} 5$, ATP 3, potassium oxalate $5, \mathrm{NaN}_{3} 5, \mathrm{CaCl}_{2} 0.02$ plus ${ }^{45} \mathrm{Ca}\left(2-3 \times 10^{4} \mathrm{cpm} / \mathrm{ml}\right)$ and histidine buffer $30(\mathrm{pH} 7.4)$ according to the method of Takayanagi et al. (13). Ca-release was examined by 10 -fold dilution of the suspension of microsomes with the solution containing ( $\mathrm{mM}$ ) $\mathrm{KCl} 100, \mathrm{MgCl}_{2} 5$ and histidine buffer 30 ( $\mathrm{pH}$ 7.4) according to the method of Takayanagi et al. (14). To study the mechanical responses of the taenia to $\mathrm{CaCl}_{2}$, after the taenia was well rinsed in $\mathrm{Ca}$-free-solution $\left(\mathrm{CaCl}_{2}\right.$ was omitted) or Ca-free- $\mathrm{KCl}$-solution $\left(\mathrm{CaCl}_{2}\right.$ was omitted and $\mathrm{NaCl}$ was replaced by $\mathrm{KCl}$ ), $\mathrm{CaCl}_{2}$ was added and the response was recorded isotonically. To measure the alterations of ${ }^{42} \mathrm{~K}$-efflux, the tissues were equilibrated for $3 \mathrm{hr}$ in ${ }^{42} \mathrm{~K}$-physiological solution $\left({ }^{42} \mathrm{~K} 10 \mu \mathrm{Ci} / \mathrm{ml}\right)$ and then transferred to inactive solution. The radioactivity was counted in an $\gamma$-counter (15).

\section{RESULTS}

Phenylephrine $\left(10^{-6} \mathrm{~g} / \mathrm{ml}\right)$ relaxed the taenia maximally and the relaxation was not 
affected by propranolol $\left(10^{-6} \mathrm{~g} / \mathrm{ml}\right)$. Therefore, changes in levels of the intracellular cyclic nucleotides were measured after the treatment with the above concentration of the drugs. Treatment with phenylephrine did not change the intracellular cyclic AMP and GMP levels in the taenia, as compared with the control (Table 1). The protein content of one preparation was 2-4 mg for cyclic AMP assay and 15-20 mg for cyclic GMP.

In the present study, phenylephrine $\left(3 \times 10^{-6} \mathrm{~g} / \mathrm{ml}\right)$ hyperpolarized the membrane and abolished the spontaneous spikes. These phenomena were accompanied by a decrease in tension. These effects of phenylephrine were blocked by dibenamine $\left(10^{-6} \mathrm{~g} / \mathrm{ml}\right.$ ) (data not shown). Since the spike in smooth muscle is thought to be mainly Ca-dependent, phenylephrine may have an influence on the transmembrane Ca-movement. Therefore, we measured Ca-movement in intact muscles. To ascertain whether or not phenylephrine supresses the

TABLE 1. Effects of phenylephrine on the tissue levels cyclic AMP and cyclic GMP in the guinea pig taenia caecum

\begin{tabular}{|c|c|c|c|c|}
\hline & $\begin{array}{c}\text { cyclic AMP levels } \\
\text { (mean s.e.) } \\
\text { (pmoles/mg protein) }\end{array}$ & $\begin{array}{c}\% \\
\text { (mean }+ \text { s.e.) }\end{array}$ & $\begin{array}{l}\text { No. of } \\
\text { experiments }\end{array}$ & p-value \\
\hline $\begin{array}{l}\text { phenylephrine }\left(10^{-6} \mathrm{~g} / \mathrm{ml}\right) \\
+ \text { propranolol }\left(10^{-6} \mathrm{~g} / \mathrm{ml}\right)\end{array}$ & $4.17-0.32$ & $115: 12$ & 6 & $\mathrm{p}>0.05$ \\
\hline \multirow[t]{2}{*}{ control } & $3.82 \div 0.43$ & 100 & 6 & \\
\hline & $\begin{array}{c}\text { cyclic GMP levels } \\
\text { (mean }- \text { s.e.) } \\
\text { (pmoles/mg protein) }\end{array}$ & $\begin{array}{c}\% \\
(\text { mean } \div \text {-s.e. })\end{array}$ & $\begin{array}{l}\text { No. of } \\
\text { experiments }\end{array}$ & p-value \\
\hline $\begin{array}{l}\text { phenylephrine }\left(10^{-6} \mathrm{~g} / \mathrm{ml}\right) \\
+ \text { propranolol }\left(10^{-6} \mathrm{~g} / \mathrm{ml}\right)\end{array}$ & $0.30 \longleftarrow 0.06$ & $100 \pm 12$ & 6 & $\mathrm{p}>0.05$ \\
\hline control & $0.31 \pm 0.06$ & 100 & 6 & \\
\hline
\end{tabular}

The paired $t$-test was used.

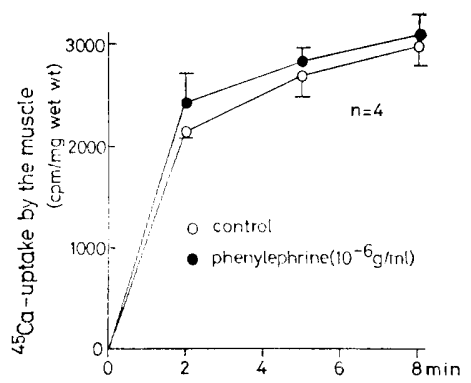

FiG. 1. Uptake of ${ }^{45} \mathrm{Ca}$ by the taenia in the presense $(O)$ or absence $(\bigcirc)$ of phenylephrine $\left(10^{-6} \mathrm{~g} / \mathrm{ml}\right)$. Vertical bars indicate the standard errors. Abscissa: Time $(\mathrm{min})$ in ${ }^{45} \mathrm{Ca}$ solution. Ordinate: $\mathrm{cpm} / \mathrm{mg}$ wet wt. n.: no. of experiments.

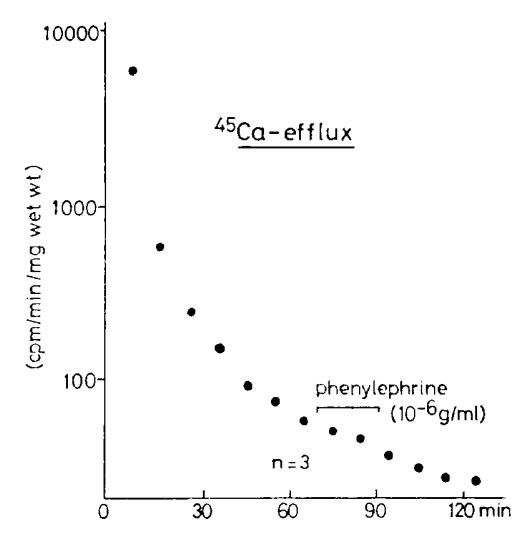

FIG. 2. Effects of phenylephrine $\left(10^{-6} \mathrm{~g} / \mathrm{ml}\right)$ on ${ }^{45} \mathrm{Ca}$-efflux from the taenia caecum. Abscissa: Time (min) after transfer from ${ }^{45} \mathrm{Ca}$-solution. Logarithmic ordinate: $\mathrm{cpm} / \mathrm{min} / \mathrm{mg}$ wet wt. n.: no. of experiments. 
uptake of calcium by the muscle, ${ }^{45} \mathrm{Ca}$-uptake was measured. As shown in Fig. 1, phenylephrine $\left(10^{-6} \mathrm{~g} / \mathrm{ml}\right)$ did not inhibit ${ }^{45} \mathrm{Ca}$-uptake by the muscle. If calcium extrusion across the plasma membrane is accelerated by a drug, the taenia will relax, therefore the effect of phenylephrine on ${ }^{45} \mathrm{Ca}$-efflux was tested. We found that this agent did not accelerate ${ }^{45} \mathrm{Ca}$ efflux (Fig. 2). Phenylephrine did not change the extracellular space.

Calcium content in the muscle may be much more than the amount moved across the plasma membrane when the muscle contracts or relaxes. A minute change in the amount of $\mathrm{Ca}$ may be obscured by a large Ca-content in the muscle. We also examined the Camovement on the subcellular level. We used the microsomal fraction which contained high concentrations of markers of plasma membrane such as $\mathrm{Na}, \mathrm{K}$-ATPase and 5 'nucleotidase (14). Ca-uptake by the microsomal fraction was accelerated by ATP ( $3 \mathrm{mM})$ and oxalate $(5 \mathrm{mM})$. Therefore, Ca-uptake was examined in the presence of ATP $(3 \mathrm{mM})$ and oxalate $(5 \mathrm{mM})$. Phenylephrine $\left(10^{-6} \mathrm{~g} / \mathrm{ml}\right)$ did not change the amount of calcium taken up. Higher doses of phenylephrine induced no change (Table 2). Phenylephrine $\left(10^{-6} \mathrm{~g} / \mathrm{ml}\right)$ had no significant effect on Ca-release regardless of the time of incubation (Fig.

3). Higher doses $\left(2 \times 10^{-5}\right.$ and $\left.10^{-3} \mathrm{~g} / \mathrm{ml}\right)$ of phenylephrine also had no effect.

It is generally considered that the smooth muscle membrane depolarizes slightly in Ca-free-solution and greatly depolarizes considerably in $\mathrm{Ca}$-free- $\mathrm{KCl}$-solution. To study the mechanical responses of the taenia to $\mathrm{CaCl}_{2}, 0.5 \mathrm{mM} \mathrm{CaCl}_{2}$ was added to the organ bath filled with $\mathrm{Ca}$-free-solution or $\mathrm{Ca}$-free- $\mathrm{KCl}$-solution. In $\mathrm{Ca}$-free- $\mathrm{KCl}$-solution, phenylephrine $\left(10^{-6} \mathrm{~g} / \mathrm{ml}\right)$ added before or after $\mathrm{CaCl}_{2}$-addition slightly modified the response of the taenia to $0.5 \mathrm{mM} \mathrm{CaCl}_{2}$ (Fig. 4). Phenylephrine $\left(10^{-6} \mathrm{~g} / \mathrm{ml}\right)$ inhibited the response of the taenia to $0.5 \mathrm{mM} \mathrm{CaCl}_{2}$ in Ca-free-solution (Fig. 4). In Ca-free-solution, phenylephrine $\left(10^{-6} \mathrm{~g} /\right.$ $\mathrm{ml}$ ) inhibited the dose response curve of $\mathrm{CaCl}_{2}$ and this effect was blocked by phentolamine $\left(10^{-6} \mathrm{~g} / \mathrm{ml}\right)$. Since variance in the response to $\mathrm{CaCl}_{2}$ was rather large in Ca-free- $\mathrm{KCl}$ solution, the difference between values before and after phenylephrine-treatment was not significant (Fig. 5).

TABLE 2. Effect of phenylephrine on calcium uptake by the microsomal fraction

\begin{tabular}{|c|c|c|c|}
\hline & \multicolumn{3}{|c|}{ nmoles $\mathrm{Ca} / \mathrm{mg}$ protein (mean \pm s.e.) } \\
\hline & $2 \min$ & $6 \min$ & $10 \mathrm{~min}$ \\
\hline control & $5.4 \pm 0.6$ & $11.5 \pm 1.0$ & $15.4 \pm 1.3(n=5)$ \\
\hline $\begin{array}{l}\text { phenylephrine } \\
\qquad\left(1 \times 10^{-6} \mathrm{~g} / \mathrm{ml}\right)\end{array}$ & $5.0 \pm 0.5$ & $10.8 \pm 0.7$ & $15.5 \pm 1.0(n=5)$ \\
\hline control & $5.2+0.2$ & $8.6 \pm 0.1$ & $9.7 \pm 0.3(n=6)$ \\
\hline $\begin{array}{l}\text { phenylephrine } \\
\qquad\left(2 \times 10^{-5} \mathrm{~g} / \mathrm{ml}\right)\end{array}$ & $5.1 \pm 0.3$ & $8.3 \pm 0.2$ & $10.2 \pm 0.1 \quad(n=6)$ \\
\hline control & $7.1 \pm 0.2$ & $10.8 \pm 0.4$ & $13.4 \pm 0.5(n=5)$ \\
\hline $\begin{array}{l}\text { phenylephrine } \\
\qquad\left(1 \times 10^{-3} \mathrm{~g} / \mathrm{ml}\right)\end{array}$ & $6.7 \pm 0.2$ & $11.0 \pm 0.6$ & $13.3 \pm 0.8(\mathrm{n}=5)$ \\
\hline
\end{tabular}

Values represent the amount (nmoles $\mathrm{Ca} / \mathrm{mg}$ protein) of calcium taken up. $\mathrm{n}$ : no of experiments. 


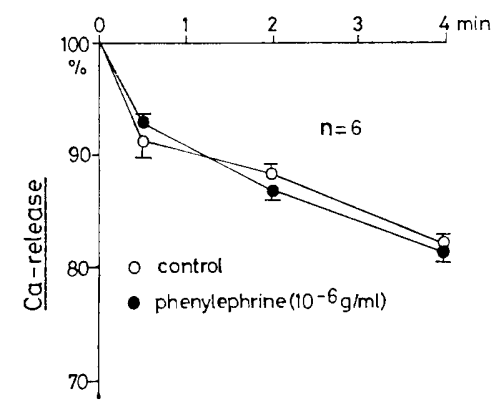

FIG. 3. Effect of phenylephrine $\left(10^{-6} \mathrm{~g} / \mathrm{ml}\right)$ on Ca-release from the microsomal fraction of taenia caecum. Vertical bars indicate the standard errors. Abscissa: Time (min) after the dilution. Ordinate: percentage of the amount of calcium in microsomes. The amount of calcium at 0 time was considered as $100 \%$. n.: no. of experiments.

Ca'free-solution

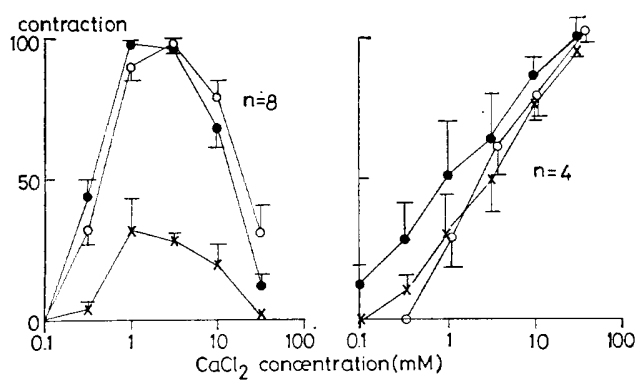

FIG. 5. Effect of phenylephrine on the response of taenia to $\mathrm{CaCl}_{2}$. Vertical bars indicate the standard errors. Left; : control, $x$ : with phenylephrine $\left(10^{-6} \mathrm{~g} / \mathrm{ml}\right), O$ : with phenylephrine $\left(10^{-6} \mathrm{~g} / \mathrm{ml}\right)$ plus phentolamine $\left(10^{-6}\right.$ $\mathrm{g} / \mathrm{ml}$ ). right; $:$ the first control, $O$ : the second control, $x$ : with phenylephrine $\left(10^{-6} \mathrm{~g} / \mathrm{ml}\right)$

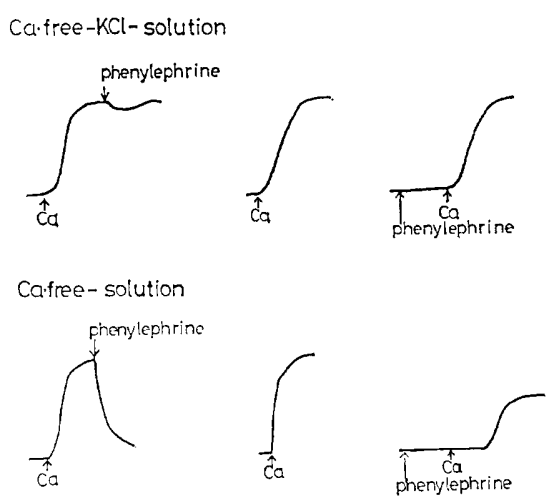

FIG. 4. Effect of phenylephrine $\left(10^{-6} \mathrm{~g} / \mathrm{ml}\right)$ on the response of taenia to $0.5 \mathrm{mM}$ $\mathrm{CaCl}_{2}$ in $\mathrm{Ca}$ free-KCl-solution and $\mathrm{Ca}$ free-solution. The mechanical responses were recorded isotonically.

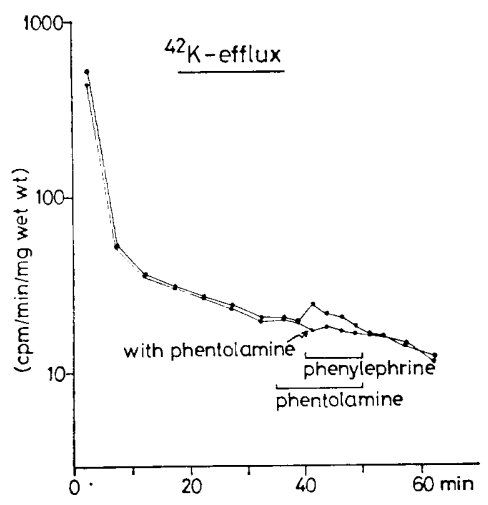

FIG. 6. Effect of phenylephrine $\left(10^{-6} \mathrm{~g} / \mathrm{ml}\right)$ on ${ }^{42} \mathrm{~K}$-efflux from the taenia caecum. Abscissa: Time (min) after transfer from ${ }^{42} \mathrm{~K}$-solution. Logarithmic ordinate: $\mathrm{cpm} / \mathrm{min} / \mathrm{mg}$ wet wt. Phenylephrine was present from $40 \mathrm{~min}$ to $50 \mathrm{~min}$. Phentolamine $\left(10^{-6} \mathrm{~g} / \mathrm{ml}\right)$ was present from $35 \mathrm{~min}$ to $50 \mathrm{~min}$.

Outward current by potassium can be electrophysiologically observed during $\alpha$ adrenergic action (16). Jenkinson and Morton (6, 7) and Bülbring et al. (17) observed ${ }^{42} \mathrm{~K}$-efflux increased by $\alpha$-adrenoceptor stimulant in the K-depolarized taenia. Their observations were confirmed in this study (data not shown). In order to ascertain the participation of any change of K-permeability which would induce relaxation in the muscle, we examined ${ }^{42} \mathrm{~K}$-efflux in normal undepolarized taenia. Phenylephrine $\left(10^{-6} \mathrm{~g} / \mathrm{ml}\right)$ increased ${ }^{42} \mathrm{~K}$-efflux and this effect of phenylephrine was blocked by phentolamine $\left(10^{-6} \mathrm{~g} / \mathrm{ml}\right)$ (Fig. 6). 


\section{DISCUSSION}

In smooth muscle the tissue levels of cyclic AMP are increased by isoprenaline and levels of cyclic GMP are increased by drugs which contract smooth muscle (18). In our laboratory, Ohkubo et al. (19) reported that isoprenaline increased the tissue levels of cyclic AMP and decreased levels of cyclic GMP in tracheal smooth muscle. In the present study it was indicated that phenylephrine did not change these levels in the taenia. This result suggests that $\alpha$-adrenergic action in the intestinal smooth muscle is not mediated through a change in levels of intracellular cyclic nucleotides. Our results coincide with the findings that $\alpha$-adrenergic action is not mediated through cyclic AMP in rat liver (20), heart (21) and intestinal smooth muscles $(22,23)$.

Since the spike in smooth muscle is thought to be mostly Ca-dependent, drugs which inhibit the spike discharge probably affect the transmembrane Ca-movement. It has been reported that papaverine inhibits ${ }^{45} \mathrm{Ca}$-uptake by the uterus (24) and by the taenia caecum of guinea pig $(15,25)$. In the present study, phenylephrine was without any effect on ${ }^{45} \mathrm{Ca}$ release from the taenia caecum. These results may indicate that phenylephrine does not influence Ca-movement across the membrane. But if the amount of calcium which was moved by phenylephrine is minute, a change of Ca-content in the muscle may be undetectable by the methods used.

Phenylephrine had no influence on ${ }^{45} \mathrm{Ca}$-uptake by the microsomes of the taenia caecum and ${ }^{45} \mathrm{Ca}$-release from these microsome. Other workers reported that epinephrine, isoprenaline and papaverine, which increase intracellular levels of cyclic AMP, increased ${ }^{45} \mathrm{Ca}$-uptake by the microsomal fractions from some smooth muscles $(4,14,26,27)$. On the other hand, some smooth muscle relaxants, which have no influence on the intracellular levels of cyclic AMP, inhibited ${ }^{45} \mathrm{Ca}$-uptake by the intestinal microsomal fractions (13, $27-$ 29). Furthermore, smooth muscle stimulants, such as angiotensin II $(26,30)$ and acetylcholine (14) accelerated ${ }^{45} \mathrm{Ca}$-release from the microsome of smooth muscles. There is accumulating evidence that actions of the drugs affecting smooth muscle contraction and relaxation are related to their effects on calcium transporting properties of microsomal fractions. The present results suggest that phenylephrine does not influence either Cauptake or-release at least under the experimental conditions used. There may be room for improvement in the experimental conditions, such as ATP concentration in the incubation medium (31) and purification of the crude microsomal fraction.

Jenkinson and Morton $(6,7)$ reported that ${ }^{42} \mathrm{~K}$-efflux was increased by $\alpha$-adrenergic action in the K-depolarized taenia caecum from guinea pig which was not relaxed by the $\alpha$-adrenoceptor stimulant. Furthermore Bülbring et al. (17) reported that epinephrine increased the rate of ${ }^{42} \mathrm{~K}$-efflux in smooth muscle which was completely depolarized by $\mathrm{K}_{2} \mathrm{SO}_{4}$ and that this effect was less in muscle partly depolarized by $\mathrm{KCl}$ and was smaller in normal solution. It has been clearly demonstrated in the present study that ${ }^{42} \mathrm{~K}$-efflux in the normal undepolarized smooth muscle is also increased by the $\alpha$-adrenoceptor stimulant. The results obtained suggest that the increase of K-efflux induced by phenylephrine hyperpolarized the membrane and relaxed the taenia caecum. 
In the present study, phenylephrine inhibited the mechanical responses to $\mathrm{CaCl}_{2}$ in $\mathrm{Ca}-$ free-solution but not those in $\mathrm{Ca}-$ free- $\mathrm{KCl}$-solution. Membrane is depolarized slightly in Ca-free-solution and considerably in Ca-free- $\mathrm{KCl}$-solution. The hyperpolarization induced by phenylephrine apparently does not counteract large depolarization in Ca-free$\mathrm{KCl}$-solution.

\section{REFERENCES}

1) Ahlquist, R.P.: A study of the adrenergic receptor. Am. J. Physiol. 153, 586-600 (1948)

2) Ahlquist. R.P. ANd Levy, B.: Adrenergic receptive mechanism of canine ileum. J. Pharmacol. exp. Ther. 127, 146-149 (1959)

3) ANDERsson, R.: Role of cyclic AMP and $\mathrm{Ca}$ in the metabolic and relaxing effects of catecholamines in intestinal smooth muscle. Acta physiol. scand. 85, 312-322 (1972)

4) Nitsson, K.: Ca-binding and release in smooth muscle sarcoplasmic reticulum in relation to cyclic AMP. Acta physiol. scand. Suppl. 396, 4 (1973)

5) Bülbring, E. ANd Tomita, T.: Increase of membrane conductance by adrenaline in the smooth muscle of guinea-pig taenia coli. Proc. R. Soc. B. 172, 80-102 (1969)

6) Jenkinson, D.H. ANd Morton, I.K.M.: The effect of noradrenaline on the permeability of depolarized intestinal smooth muscle to inorganic ions. J. Physiol. 188, 373-386 (1967)

7) Jenkinson, D.H. ANd Morton, I.K.M.: The role of $\alpha$ - and $\beta$-adrenergic receptors in some actions of catecholamines of intestinal smooth muscle. J. Physiol. 188, 387-402 (1967)

8) Gilman, A.G.: A protein binding assay for adenosine $3^{\prime}, 5^{\prime}$-cyclic monophosphate. Proc. natn. Acad. Sci. U.S.A. 67, 305-312 (1970)

9) Steiner, A.L., Parker, C.W. and KiPnis, D.M.: Radioimmunoassay for cyclic nucleotides. J. biol. Chem., 247, 1106-1113 (1972)

10) Yasuda, H., Yamada, M. and Kurata, S.: Intracellular cGMP level and cell increase. Seikagaku, 46, 618 (1974) (in Japanese)

11) Lowry, O.H., Rosebrough, N.J., FarR, A.L. and Randall, R.J.: Protein measurement with the Folin phenol reagent. J. biol. Chem. 193, 265-275 (1951)

12) Bülbring, E. AND BURNSTOCK, G.: Membrane potential changes associated with tachyphylaxis and potentiation of the response to stimulating drugs in smooth muscle. Brit. J. Pharmacol. 15, 611-624 (1960)

13) Takayanagi, I., Yamashita, H., Manda, T. and Takagi, K.: Calcium ions and relaxation of intestinal smooth muscle induced by papaverine and Aspaminol. Japan. J. Pharmacol. 27, 311-314 (1977)

14) Takayanagi, I., Hongo, T. and Kasuya, Y.: Difference in the mechanisms by which acetylcholine and histamine interact with $\mathrm{Ca}^{2+}$ to contract the rabbit taenia coli. J. Pharm. Pharmacol. 29, 775-776 (1977)

15) Tomiyama, A., Takayanagi, I. and Takagi, K.: Relaxation of intestinal smooth muscle and calcium movements. J. Pharm. Pharmacol. 25, 65-68 (1973)

16) Tomita, T., Sakamoto, Y. and Ohba, M.: Conductance increase by adrenaline in guinea pig taenia coli studied with voltage clamp method. Nature 250, 432-433 (1974)

17) Bülbring, E., Goodford, P.J. And Setekleiv, J.: The action of adrenaline on the ionic content and on sodium and potassium movements in the smooth muscle of the guineapig taenia coli. Brit. J. Pharmacol. 28, 296-307 (1966)

18) Andersson, R., Nilsson, K., Wikberg, J., Johansson, S., Mohme-Lundhorm, E. and Lundholm, L.: Cyclic nucleotides and the contraction of smooth muscle. Advances in Cyclic Nucleotide Research, Edited by Greengard, P. and Robison, G.A., Vol. 5, p. 491-518, Raven Press, New York (1975)

19) Ohkubo, H., Takayanagi, I. and Takagi, K.: Relationship between the levels of intracellular cyclic nucleotides and mechanical responses induced by drugs. Japan. J. Pharmacol. 26, 65-71 (1976)

20) Cherrington, A.D., Assimacopoulos, F.D., Harper, S.C., Corbin, J.D., Park, C.R. and Exton, J.H.: Studies on the $\alpha$-adrenergic activation of hepatic glucose output. $J$. biol. Chem. 251, 5209-5218 (1976) 
21) OsNes, J.B. AND ØYE, I.: Relationship between cyclic AMP metabolism and inotropic response of perfused rat hearts to phenylephrine and other adrenergic amines, Advances in Cyclic Nucleotide Research, Edited by Greengard, P. AND Robison, G.A., Vol. 5, p. 415-433, Raven Press, New York (1975)

22) Andersson, R., Lundholm, L., Mohme-Lundholm, E. and Nilsson, K.: Role of cyclic $\mathrm{AMP}$ and $\mathrm{Ca}$ in metabolic and mechanical events in smooth muscle, Advances in Cyclic Nucleotide Research, Edited by Greengard, P. And Robison, G.A., Vol. 1, p. 439-455, Raven Press, New York (1972)

23) Takayanagi, I., Uchida, M., Inatomi, N., Tomiyama, A. and Takagi, K.: Intracellular cyclic adenosine $3^{\prime}, 5^{\prime}$-monophosphate and relaxing effects of isoprenaline and papaverine on the smooth muscle of intestine. Japan. J. Pharmacol. 22, 869-871 (1972)

24) CARSTEn, M.E.: Role of calcium binding by sarcoplasmic reticulum in the contraction and relaxation of uterine smooth muscle. J. gen. Physiol. 53, 414-426 (1969)

25) Takayanagi, I., Karasawa, A. and Kasuya, Y.: Relaxation of depolarized guinea pig taenia caecum induced by some antispasmodics. Europ. J. Pharmacol. 50, 137-143 (1978)

26) Baudouin-Leglos, M. ANd Meyer, P.: Effects of angiotensin, catecholamines and cyclic AMP on calcium storage in aortic microsomes. Brit. J. Pharmacol. 47, 377-385 (1973)

27) Crankshaw, D.J., Janis, R.A. and Daniel, E.E.: The effects of $\mathrm{Ca}^{2+}$ antagonists on $\mathrm{Ca}^{2+}$ accumulation by subcellular fractions of rat myometrium. Canad. J. Physiol. Pharmacol. 55, 1028-1032 (1977)

28) Takayanagi, I., Yamashita, K. and Kasuya, Y.: Nonspecific relaxation of intestinal smooth muscle induced by antispasmodics and movement of calcium ions. Japan. $J$. Pharmacol. 28, 334-337 (1978)

29) Uchida, M.: Active extrusion of calcium ions by smooth muscle microsomes. Biochem. biophys. Res. Commun. 73, 127-137 (1976)

30) Baudouin, M. and Meyer, P.: Calcium release induced by interaction of angiotensin with its receptors in smooth muscle cell microsomes. Nature 235, 336-338 (1972)

31) Nishikori, K., Takenaka, T. and Maeno, H.: Stimulation of microsomal calcium uptake and protein phosphorylation by adenosine cyclic $3^{\prime}, 5^{\prime}$-monophosphate in rat uterus. Mol. Pharmacol. 13, 671-678 (1977) 